\title{
Seed Shatter Dates of Antelope Bitterbrush in Oregon
}

\author{
G. R. Johnson ${ }^{1}$ and Paul C. Berrang ${ }^{2}$ \\ Authors are ${ }^{1}$ Research Geneticist, USDA Forest Service, Corvallis, OR 97331-4401; \\ and ${ }^{2}$ Regional Geneticist, USDA Forest Service Region 9, Milwankee, WI 53202.
}

\begin{abstract}
Seed shatter dates for antelope bitterbrush (Purshia tridentata [Pursh] DC) were estimated from collections at 192 sites in Oregon and surrounding states. Shatter date was strongly correlated to elevation $(r=0.74)$ and an equation that included elevation, latitude, longitude, and longitude squared explained $79 \%$ of the variation in seed shatter dates. In general, earlier shatter dates were associated with more southerly latitudes, easterly longitudes, and lower elevations. Examination of climatic data confirmed the expectation that earlier shatter dates were associated with warmer sites. This information can assist those needing to schedule seed collection activities at multiple locations.

\section{Resumen}

Se estimaron las fechas de liberación de la semilla del “Antelope bitterbrush" (Purshia tridentata [Pursh] DC) de colecciones de 192 sitios de Oregon y los estados circunvecinos. La fecha de liberación estuvo fuertemente correlacionada con la elevación $(r=$ 0.74) y una ecuación que incluyó la elevación, latitud, longitud y longitud cuadrada explicó 79\% de la variación de las fechas de liberación de la semilla. En general las fechas más tempranas estuvieron asociadas con las latitudes más al sur y las longitudes más al este y bajas elevaciones. El examen de los datos climáticos confirmaron la expectativa de que fechas tempranas de liberación de semilla estaban asociadas a sitios más calientes. Esta información puede asistir a aquellas personas que necesitan programar actividades de colecta de semilla en localidades múltiples.
\end{abstract}

Key Words: Purshia tridentata, seed collection, seed maturation

\section{INTRODUCTION}

Antelope bitterbrush (Purshia tridentata [Pursh] DC) is an important shrub used in landscape restoration in the western United States. This shrub is an important component of the Intermountain Zone and is a key forage plant for large mammals (mule deer, elk, and pronghorn antelope: Nord 1965; Kufeld 1973; Kufeld et al. 1973; Stuth and Winward 1977; Guenther et al. 1993) and a seed source for granivores (Vander Wall 1994; Young and Clements 2002). Most seed for restoration is obtained from wildland collections. These collections must be appropriately timed because seed shatter for bitterbrush stands occurs over a period of a very few days following seed maturation (Nord 1965; Shaw and Monsen 2004). If collectors arrive too early, the seed cannot be easily removed from the plants and if they arrive too late, the seed is already on the ground.

Phenology, in general, is tied to the heat units accumulated over the season (see reviews by Wang 1960 and Wielgolaski 1999) and seed shatter date would logically follow the same model. Shelford (1930) pointed out that Réaumur (1735) was one of the first to note that one could predict a phenological stage better with heat sums than with calendar days. Predicting

Research was funded in part by a grant from the Cooperative State Research, Education, and Extension Service, Managed Ecosystems Program.

Correspondence: Randy Johnson, USDA Forest Service, Forestry Sciences Lab, 3200 SW Jefferson Way, Corvallis, OR 97331-4401. Email: randyjohnson@fs.fed.us

Manuscript received 5 January 2006; manuscript accepted 18 August 2006. seed shatter dates by summing heat units for each potential collection site is impractical in practice. Another complicating factor is that seed sources of the same species can differ in the heat sums required for particular phenological stages (e.g., Campbell 1974; Frank et al. 1985). Common garden studies in forest trees have demonstrated that these population differences also tend to be associated with the climate from where the population is collected (e.g., Rehfeldt et al. 1999; St. Clair et al. 2005). Because geography (latitude, longitude, and elevation) is closely related to temperature (e.g., Rehfeldt et al. 1999), these variables could be used as surrogates for heat sums.

Nord (1965) used elevation and latitude of collection site to predict seed shatter dates for 29 locations in California with reasonable accuracy $\left(R^{2}=0.74\right)$. Alderfer (1976) also found a strong association between elevation and seed shatter date for 18 locations in Oregon, but found that the ripening dates predicted by Nord's equation were not suitable for the Oregon locations.

In 2002, a major collection effort was made, predominantly in Oregon, but also in surrounding states, to obtain bitterbrush populations for a genecology study. The objective was to make collections at many locations throughout the range of the species and plant them in a common garden (see Johnson et al. 2004 for a general description). Most collections were of single plants, but a subset were multiple-plant collections. Seed shatter dates varied widely among locations and seemed to be associated with physiographic variables. The objective of this paper was to use the collection information to develop an equation to predict seed shatter dates in Oregon based on elevation, latitude, and longitude. Such information would 
Table 1. Means and ranges for variables describing 192 antelope bitterbrush seed collection sites.

\begin{tabular}{lccc}
\hline Variable & Mean & Minimum & Maximum \\
\hline Shatter date (Julian) & 193.9 & 157 & 222 \\
Latitude $\left(\right.$ decimal $^{\circ}$ ) & 43.859 & 41.52 & 46.349 \\
Longitude $\left(\right.$ decimal $^{\circ}$ ) & -120.148 & -122.11 & -117.053 \\
Elevation $(\mathrm{m})$ & 1191 & 90 & 2043 \\
\hline
\end{tabular}

be beneficial to those making wildland seed collections in the future.

\section{METHODS AND MATERIALS}

Bitterbrush seed were collected at 251 sites during the summer of 2002. Sites were visited every 7 to 10 days until seed shatter or until seeds were in the "blood stage." The "blood stage" occurs just prior to achene maturation when the seeds are firm and the surrounding liquid is dark red (Shaw et al. 2004). Experience had shown that if seed was at this stage, seed shatter would occur before we could return a week later. Consequently, branches with good seed crops were cut and placed in a large paper grocery bag. Seeds were allowed to mature and shatter inside the bag. For these collections, 4 days (approximately one-half of the collection interval) was added to the actual collection date to estimate the seed shatter date. For 13 collections, seed shatter was missed and seeds were collected from the ground; 4 days were subtracted from the collection date to estimate the shatter date.

Only the 192 sites that produced at least 100 sound seeds (Table 1) were used for further investigation. Sound seed were those that appeared plump and filled. Black and shriveled seeds were discarded. Climatic data for these 192 sites were obtained from GIS coverages generated from PRISM (Parameter-Elevation Regressions on Independent Slopes Model, Daly et al. 1994; see www.ocs.orst.edu/prism/prism_new.html). Climate variables included monthly mean, minimum and maximum temperatures, monthly precipitation, date of last spring and first fall frosts, and number of frost-free days.

Simple correlations between the estimated seed-shatter date and geographic and climatic variables were examined. Regression equations were built with the REG procedure of SAS (SAS Institute Inc. 1999). Simple models using geographic variables were first examined and compared with those developed by Nord (1965) for California. Climatic variables were then examined to see whether the predictive value of the equations could be improved. Confidence intervals for the predicted dates were estimated as the square root of the mean square error $(\sigma)$ times the $t$ value for the model $\left(t_{(190,0.05)}=1.96\right)$.

To verify the final equation, seed shatter date was predicted for Alderfer's 18 Oregon and 2 California populations. Latitude and longitude for the collections were estimated from Fig. 1 in Alderfer (1976). For the 3 populations that were collected early, 4 days were added to obtain the expected seed shatter date. Likewise, 4 days were subtracted from the shatter date of the one population that was collected late.

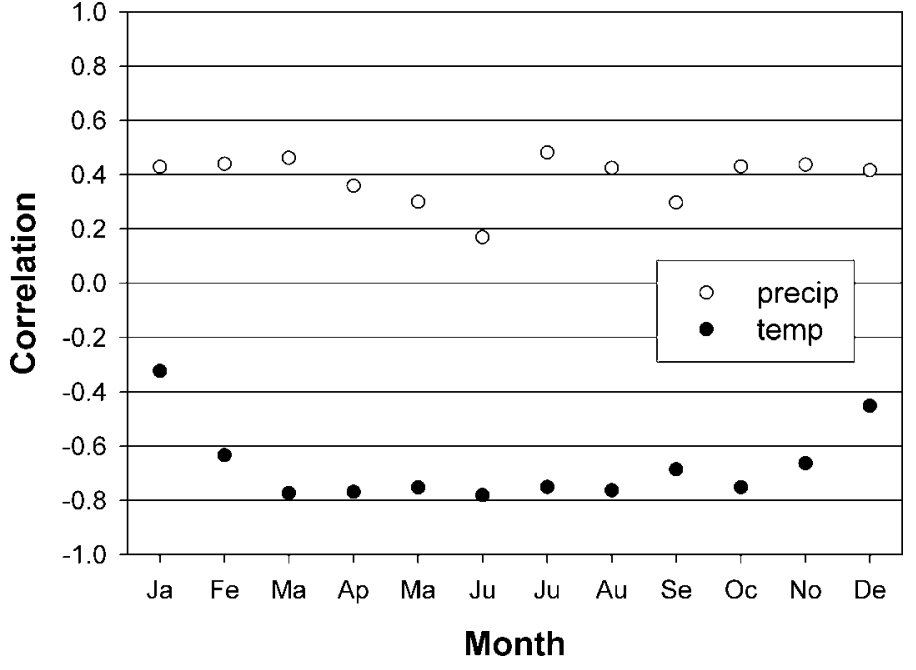

Figure 1. Correlations of mean monthly temperature and precipitation with seed shatter date.

Germination data were obtained on 134 of the 2002 collections from a common garden sown in raised beds in 2005. Seed were stratified for 40 days at $1^{\circ} \mathrm{C}$ before sowing. Final germination was measured 6 weeks after planting.

\section{RESULTS AND DISCUSSION}

The addition of 4 days to the branch-collected seed lots to obtain seed shatter dates seemed reasonable because germination percentage of these collection sites was the same as from sites with mature seed. Germination in the common garden of the branch-collected seed ( 45 collections, germination $=69 \%$ ) was not statistically different $(P=0.622)$ from germination of mature seed (germination $=70 \%$ ) collected from shrubs $(n=81)$ and the ground $(n=8)$. Had collection dates been too early, we would have expected germination to have been reduced. On 2 plants, where weekly seed collections were made during the summer of 2004, we found that germination of seeds collected a week before seed shatter had equal or better germination than seed collected during seed shatter. However, seeds collected 2 weeks prior to seed shatter exhibited a drop in germination $(33 \%$ and $4 \%)$ relative to those collected during seed shatter $(92 \%$ and $33 \%)$.

The correlations of latitude, longitude, elevation, and seedshatter date are shown in Table 2. Of the three, elevation had the strongest correlation with shatter date $(r=+0.604)$, followed by longitude and latitude. Latitude and elevation were highly correlated $(r=-0.804)$; the higher elevations being found at the lower latitudes. This strong correlation between two independent variables used in our final regression model limits the applicability of the prediction equation to the range sampled in this study (Neter and Wasserman 1974). This limitation is probably one reason that Nord's (1965) California equation did not fit Alderfer's (1976) Oregon data.

Seed shatter dates were more strongly correlated with monthly temperatures (correlations ranged from -0.32 to -0.78 ) than with monthly precipitation (correlations ranged from 0.17 
Table 2. Correlations $(r)$ among latitude, longitude, elevation, average spring (March-May) and summer (June-August) temperatures, and antelope bitterbrush seed-shatter date ( $P$ values in parentheses).

\begin{tabular}{|c|c|c|c|c|c|c|}
\hline & Latitude & Longitude & Elevation & Spring temp. & Summer temp. & Shatter date \\
\hline Latitude & 1 & $-0.111(0.126)$ & $-0.804(<0.001)$ & $0.537(<0.001)$ & $0.388(<0.001)$ & $-0.222(0.002)$ \\
\hline Longitude & & 1 & $-0.043(0.555)$ & $0.337(<0.001)$ & $0.442(<0.001)$ & $-0.481(<0.001)$ \\
\hline Elevation & & & 1 & $-0.771(<0.001)$ & $-0.628(<0.001)$ & $0.604(<0.001)$ \\
\hline Spring temp. & & & & 1 & $0.958(<0.001)$ & $-0.768(<0.001)$ \\
\hline Summer temp. & & & & & & $-0.742(<0.001)$ \\
\hline
\end{tabular}

to 0.48$)$. The climate variables having the strongest correlation with shatter date were spring and summer temperatures (Fig. 1). The spring and summer temperatures also had higher correlations than the geographic variables with seed shatter date (Table 2). This would be expected because heat sums would be more directly related to temperature averages than to geographic variables. The geographic variables were correlated with the average temperatures (Table 2), and it is probably this relationship that allows one to use geographic variables to estimate seed shatter. Elevation had higher correlations with spring and summer monthly temperatures $(-0.5$ to -0.8$)$ than did latitude and longitude.

The regression equation parameter estimates using latitude and elevation to predict shatter date are shown in Table 3. This 2 -variable equation suggests that shatter date increases by a day (1 day later) for an increase in $29 \mathrm{~m}$ of elevation or moving north $0.14^{\circ}\left(8.6^{\prime}\right)$ of latitude. This corresponds well to Nord's estimate of a 1 day increase for each $30 \mathrm{~m}$ increase in elevation; but is about half of Nord's estimate of a 1 day increase for each increase of $0.25^{\circ}\left(15^{\prime}\right)$ latitude. Nord achieved a higher $R^{2}$ with his 2-variable model compared to the 2 -variable model presented here $(0.74$ vs. 0.56$)$. This could have occurred simply because our estimates of shatter date were coarser, because we visited our sites less frequently. Although longitude was not significant for Nord's model, both longitude and longitude squared contributed significantly to our model (Table 3).

Because latitude and elevation were highly correlated, it is important to realize that both must be considered when using any equation. If one was to consider only latitude and ignore elevation, there would appear to be a 2-day decrease in shatter date for a $1^{\circ}$ increase (moving north) in latitude (single variable model, Table 3); this is different in both direction and magnitude compared to the regression coefficients for the 2-, 3-, and 4 -variable models because the correlated effect of elevation is confounded with the latitude effect in the single variable model. Likewise, the single-variable model for elevation underpredicts the effect of elevation if latitude is not considered (see Table 3).

Aspect (a categorical variable) and slope were added to the 4-variable model to see if additional variation could be explained. Both variables were found to be statistically significant when added individually to the model $(P<0.02)$, but the $R^{2}$ only increased from 0.79 to 0.80 for slope and to 0.81 for aspect. When both were added to the model, the second variable added was not statistically significant $(P>0.10)$. An increase in slope of $18 \%$ was associated with shatter date occurring one day earlier and there was a tendency for the more southerly aspects to shatter earlier (Table 4). In both cases, an increase in sun exposure is associated with an earlier shatter date. Whereas there were statistically significant differences in shatter date associated with slope and aspect, the added variation explained by these variables was not deemed sufficient to keep them in the final model.

The climatic variables were added to the list of potential independent variables in an effort to try to find better $R^{2}$ values. $R^{2}$ values could be increased only marginally over the 0.79 for the 4-variable model including latitude, longitude, longitude squared, and elevation (Table 5). It, therefore, did not appear that a better 4 -variable model could be found than the original 4-variable model. The 4-variable geographic model was chosen as the final model because very little additional variation could be explained with the best 5 -variable model $\left(R^{2}=0.82\right)$ or

Table 3. Regression equation parameter estimates using combinations of latitude, longitude, longitude squared, and elevation to predict seed shatter dates in Oregon.

\begin{tabular}{|c|c|c|c|c|c|c|c|c|c|c|c|c|}
\hline \multirow{2}{*}{$\begin{array}{l}\text { No. of } \\
\text { variables } \\
\text { in model }\end{array}$} & \multicolumn{2}{|c|}{ Intercept } & \multicolumn{2}{|c|}{ Latitude $\left({ }^{\circ}\right)$} & \multicolumn{2}{|c|}{ Longitude $\left({ }^{\circ}\right)$} & \multicolumn{2}{|c|}{ Longitude $^{2}$} & \multicolumn{2}{|c|}{ Elevation (100 m) } & \multirow[b]{2}{*}{$R^{2}$} & \multirow[b]{2}{*}{$\sigma^{1}$} \\
\hline & Value & SE & Value & SE & Value & SE & Value & SE & Value & SE & & \\
\hline 1 & 285 & 29 & -2.083 & 0.661 & & & & & & & 0.05 & 10.97 \\
\hline 1 & -253 & 59 & & & -3.719 & 0.491 & & & & & 0.23 & 9.87 \\
\hline 1 & 173 & 2 & & & & & & & 1.738 & 0.166 & 0.37 & 8.97 \\
\hline 2 & -153 & 35 & 6.969 & 0.757 & & & & & 3.463 & 0.233 & 0.56 & 7.47 \\
\hline 2 & -167 & 59 & -2.612 & 0.569 & -3.958 & 0.470 & & & & & 0.30 & 9.38 \\
\hline 2 & -250 & 44 & & & -3.525 & 0.368 & & & 1.682 & 0.137 & 0.57 & 7.37 \\
\hline 3 & -429 & 43 & 5.548 & 0.659 & -2.859 & 0.324 & & & 3.066 & 0.202 & 0.69 & 6.30 \\
\hline 4 & 29765 & 3141 & 6.711 & 0.554 & 503.20 & 52.65 & 2.116 & 0.220 & 3.473 & 0.171 & 0.79 & 5.17 \\
\hline
\end{tabular}


Table 4. Least square means of seed shatter date, standard error, and number of sites $(n)$ for differing aspects.

\begin{tabular}{lccc}
\hline Aspect & Shatter day & Std. err. & $n$ \\
\hline Flat & 195.4 & 0.75 & 53 \\
N & 192.3 & 1.56 & 11 \\
NE & 192.2 & 1.40 & 14 \\
E & 194.6 & 0.98 & 27 \\
SE & 192.7 & 1.13 & 21 \\
S & 190.9 & 1.17 & 19 \\
SW & 191.6 & 1.36 & 15 \\
W & 196.0 & 1.15 & 20 \\
NW & 195.1 & 2.14 & 6 \\
\hline
\end{tabular}

6-variable model $\left(R^{2}=0.84\right)$. Both these models included the same 4 geographic variables and December mean temperature (July precipitation was in the 6-variable model). Adding climatic variables to the final model would also reduce the utility of the equation because climatic variables are not as readily available as the geographic variables. Geographic variables can be obtained from standard GPS devises and internet resources.

The final 4-variable model using only geographic variables (where latitude and longitude are in decimal degrees and elevation is in $100 \mathrm{~m}$ units) was:

$$
\begin{aligned}
\text { Shatter date }= & 29765+(6.711 \times \text { latitude })+ \\
& (503.2 \times \text { longitude })+\left(2.116 \times \text { longitude }^{2}\right)+ \\
& (3.473 \times \text { elevation })
\end{aligned}
$$

Table 5. Four-variable models to predict seed shatter date with r-squares $\left(R^{2}\right) \geq 0.8$, and the top ten 4 -variable models using only climatic data.

\begin{tabular}{lllll}
\hline & \multicolumn{3}{c}{ Variables } & $R^{2}$ \\
\hline Elevation & Latitude $\times$ & Jan min temp & Feb precip & 0.805 \\
& Longitude & & & \\
Latitude & Elevation & Dec precip & Frost-free days & 0.804 \\
Elevation & Latitude $^{2}$ & Dec precip & Frost-free days & 0.804 \\
Elevation & Latitude $^{2}$ & Dec precip & Fall frost date & 0.803 \\
Latitude & Elevation & Dec precip & Fall frost date & 0.802 \\
Elevation & Latitude $\times$ & Jan min temp & Dec precip & 0.801 \\
& Longitude & & & \\
Elevation & Latitude $\times$ & Jan min temp & Nov precip & 0.801 \\
& Longitude & & & \\
Latitude & Elevation & Dec precip & Spring frost date & 0.800 \\
Jul-max-temp & Jan precip & Spring frost date & Jan mean temp & 0.747 \\
Dec-max-temp & Jan precip & Spring frost date & Jul mean temp & 0.747 \\
Jul-max-temp & Jan precip & Frost-free days & Jan mean temp & 0.747 \\
Dec-max-temp & Dec precip & Spring frost date & Jul mean temp & 0.747 \\
Dec-max-temp & Dec precip & Spring frost date & Aug mean temp & 0.746 \\
Dec-max-temp & Jan precip & Spring frost date & Aug mean temp & 0.746 \\
Jul-max-temp & Dec precip & Frost-free days & Jan mean temp & 0.745 \\
Jul-max-temp & Dec precip & Spring frost date & Jan mean temp & 0.745 \\
Jun-min-temp & Dec max temp & Jan precip & Spring frost date & 0.745 \\
Dec-max-temp & Jan precip & Frost-free days & Jul mean temp & 0.745 \\
\hline & & & &
\end{tabular}

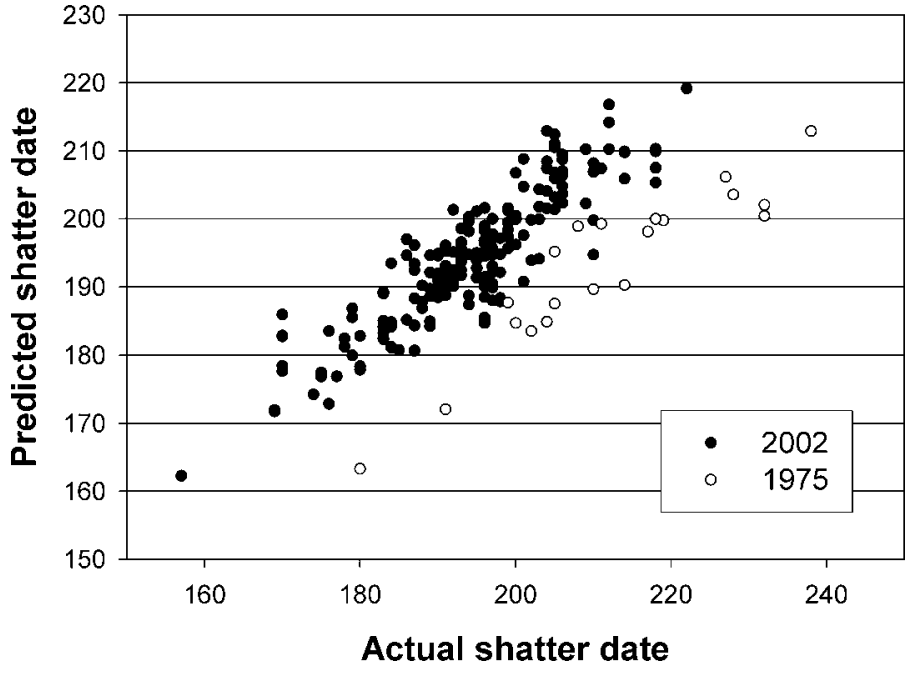

Figure 2. Plot of predicted seed shatter date and actual shatter date for the 192 locations sampled in 2002 used to make the 4-variable equation, and 20 locations sampled in 1975 (Alderford 1976) used to verify the equation.

This 4-variable model developed from the 2002 collections was used to predict the shatter dates for the 20 locations sampled by Alderfer (1976) in 1975. The 1975 collections, on average, shattered seed 19 days later than the 2002 collections, but followed the same trend (Fig 2). The earlier shattering dates in 2002 were the result of warmer spring and summer temperatures. The average temperatures in April, May, and June were $3.6^{\circ} \mathrm{C}, 10.3^{\circ} \mathrm{C}$, and $14.2^{\circ} \mathrm{C}$, respectively, in 1975 and $7.9^{\circ} \mathrm{C}, 11.1^{\circ} \mathrm{C}$, and $16.8^{\circ} \mathrm{C}$, respectively, in 2002 . The $R^{2}$ for the 1975 collection sites, after adding 19 days to the intercept, was 0.85 . Thus the equation appears to be robust for the area it was intended.

The final 4-variable model corresponded relatively well to Hopkin's "bioclimatic law," which states that in temperate North America, a phenological event will vary by 4 days for each $1^{\circ}$ in latitude, $5^{\circ}$ of longitude, and $122 \mathrm{~m}$ (400 feet) in elevation (Hopkins 1918). Because Hopkins averaged the longitude effect over the width of the United States, it is not appropriate to consider longitude for our examination of a relatively small region. However, our data conform relatively well with regard to latitude and elevation; 4 days corresponds to $0.60^{\circ}$ in latitude and $115 \mathrm{~m}$ of elevation.

Moving north $1^{\circ}$ latitude appears to delay shatter date for

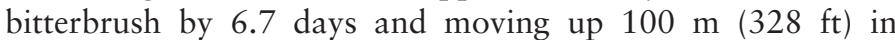
elevation appears to delay shatter date 3.5 days. For this model there is still a significant amount of variation around the predicted shatter dates (Fig 2). The calculated confidence interval $(1.96 \times \sigma)$ was 10 days.

\section{MANAGEMENT IMPLICATIONS}

This information can assist those needing to schedule seed collection activities at multiple locations. When comparing sites, differences in latitude, longitude, and elevation must be taken into account. The estimated seed shatter dates predict the relative shatter dates for multiple sites, but actual dates will vary from year to year (see also Shaw and Monsen 1983). 
Although the equations account for a substantial portion of regional variation in seed shatter as evidenced by reasonable $R^{2}$ values, one must remember that actual shatter dates could be \pm 10 days as indicated by the confidence interval. The equations only are valid for the area sampled and have not been tested in other areas.

\section{ACKNOWLEDGMENTS}

GIS information was provided by Jeff Riddle. Germination data were collected by Chris Poklemba. Seed collection personnel included: Frank and Pam Sorensen, Even and Gayle Evensen, Charley Hicks, Nancy Mandel, Dick Miles, and Al Sugano. Helpful comments were provided by Paul Anderson, Nancy Mandel, Pat Cunningham, Nancy Shaw, and 3 anonymous reviewers.

\section{LITERATURE CITED}

Alderfer J. M. 1976. A taxonomic study of bitterbrush (Purshia tridentata [Pursh] DC) in Oregon [thesis]. Corvallis, OR: Oregon State University. $197 \mathrm{p}$.

CampbelL, R. C. 1974. Use of phenology for examining provenance transfers in reforestation of Douglas-fir. Journal of Applied Ecology 11:1069-1080.

Daly C., R. P. Neilson, And D. L. Phillips. 1994. A statistical-topographic model for mapping climatological precipitation over mountainous terrain. Journal of Applied Meteorology 33:140-158.

Frank, J. F., J. D. Berdahl, and R. E. Barker. 1985. Morphological development and water use in clonal lines of four forage grasses. Crop Science 25: 339-344.

Guenther, G. E., C. L. Wambolt, and M. R. Frisina. 1993. Characteristics of bitterbrush habitats that influence canopy cover and mule deer browsing. Journal of Environmental Management 36:175-181.

HopkINS, A. D. 1918. Periodical events and natural law as guides to agricultural research and practice. Monthy Weather Review, Supplement 9:5-42.

Johnson, G. R., F. C. Sorensen, J. B. St. Clair, and R. C. Cronn. 2004. Pacific Northwest forest tree seed zones-a template for native plants? Native Plant Journal 5:131-140.

KufeLD, R. C. 1973. Foods eaten by the Rocky Mountain elk. Journal of Range Management 26:106-113.

Kufeld, R. C., O. C. Wallmo, and C. Feddema. 1973. Foods of the Rocky Mountain mule deer. Fort Collins, CO: USDA Forest Service, Rocky Mountain Forest and Range Experiment Station Research Paper RM-111. 31p.

Neter, J., and W. Wasserman. 1974. Applied linear statistical models: regression, analysis of variance, and experimental designs. Homewood, IL: Richard D. Irwin. 842 p.

Nord, E. C. 1965. Autecology of bitterbrush in California. Ecological Monographs 35:307-334.

RéAumuR, R. A. AND R. DE. 1735 (publ. 1739). Observation du thérmomére, faites à Paris pedant l'année 1735, compares avec celles qui ont été faites sous la ligne, à l'Isle de France, à Alger et quelques-unes de nos isles de l'Amerique. Mémoires de l'Académie Royal des Sciences p 545-576.

Rehfeldt, G. E., C. C. Ying, D. L. Spittlehouse, and D. A. Hamilton, JR. 1999. Genetic responses to climate in Pinus contorta: niche breadth, climate change, and reforestation. Ecological Monographs 69:375-407.

SAS Institute, Inc. 1999. SAS/STAT ${ }^{\circledR}$ User's Guide, Version 8, Cary, NC: SAS Institute, Inc. 3884 p.

Shaw, N. L., And S. B. Monsen. 1983. Phenology and growth habits of nine antelope bitterbrush, desert bitterbrush, Stansbury cliffrose, and Apache-plume accessions. In: A. R. Tiedemann and K. L. Johnson (comps.). Proceedingsresearch and management of bitterbrush and cliffrose in western North America; 13-15 April 1982; Salt Lake City, UT. General Technical Report INT152. Odgen, UT: USDA Forest Service, Intermountain Forest and Range Experiment Station. p 251-260.

Shaw, N. L. And S. B. Monsen. 2004. Purshia tridentata (Pursh) DC. In: J. K. Francis (ED.). Wildland shrubs of the United States and its territories: Thamnic descriptions. Vol. 1. General Technical Report IITF-GTR-26. San Juan, Puerto Rico: USDA Forest Service. p 610-612.

Shaw, N. L., S. B. Monsen, and R. Stevens. 2004. Rosaceous shrubs. In: S. B. Monsen, R. Stevens and N. L. Shaw (comps.). Restoring western ranges and wildlands. Vol. 2. General Technical Report RMRS-GTR-136-vol-2. Fort Collins, CO: USDA Forest Service. p 583.

Shelford, V. E. 1930. Phenology and one of its modern descendants. The Quarterly Review of Biology 5(2):207-216.

St. Clair, J. B., N. L. Mandel, and K. W. Vance-Borland. 2005. Genecology of Douglasfir in Western Oregon and Washington. Annals of Botany 96:1199-1214.

Stuth, J. W., AND A. H. Winward. 1977. Livestock-deer relations in the lodgepole pine-pumice region of central Oregon. Journal of Range Management 30: $110-116$.

Vander Wall, S. B. 1994. Seed fate pathways of antelope bitterbrush: dispersal by seed-caching yellow pine chipmunks. Ecology 75:1911-1926.

WANG, J. Y. 1960. A critique of the heat unit approach to plant response studies. Ecology 41:785-790.

Wielgolaski, F-E. 1999. Starting dates and basic temperatures in phenological observations of plants. International Journal of Biometeorology 42:158-168.

Young, J. A., And C. D. Clements. 2002. Purshia: The wild and bitter roses. Reno, NV: University of Nevada Press. 266 p. 